\title{
Fabrication and in vitro testing of polymeric delivery system for condensed DNA
}

\author{
Yen-Chen Huang, ${ }^{1,2}$ Maureen Connell, ${ }^{1}$ Youmie Park, ${ }^{1}$ David J. Mooney, ${ }^{2,3}$ Kevin G. Rice ${ }^{1}$ \\ ${ }^{1}$ College of Pharmacy, University of Michigan, Ann Arbor, Michigan 48109-1065 \\ ${ }^{2}$ Department of Biomedical Engineering, University of Michigan, Ann Arbor, Michigan 48109-1065 \\ ${ }^{3}$ Department of Chemical Engineering, College of Dentistry, University of Michigan, Ann Arbor, Michigan 48109-1065
}

Received 18 December 2002; revised 23 June 2003; accepted 14 July 2003

\begin{abstract}
Polyethylenimine (PEI) was combined with plasmid DNA and freeze dried following the addition of sucrose as a lyoprotectant and pore-forming agent. Freeze-dried PEI DNA condensates were dry mixed with granular polylactideglycolic acid (PLGA) then compression molded and sponged to encapsulated PEI DNA. A measurement of the elastic modulus indicated that $91 \mathrm{wt} \%$ sucrose substituted for $95 \mathrm{wt} \%$ sodium chloride as a porogen, resulting in PLGA sponges with a mechanical modulus of $100 \mathrm{kPa}$. The PEI DNA was retained $(80 \%)$ within PLGA sponges prepared with sucrose during the leaching and subsequent 2-week release studies, whereas sodium chloride PLGA sponges caused the premature release $(100 \%)$ of PEI DNA within 2
\end{abstract}

days. In vitro gene transfer studies with PEI DNA PLGA sponges established that adherent and infiltrating fibroblasts expressed reporter gene for 15 days compared with the short, 3-day expression mediated by direct gene of PEI DNA on cells in culture. The results demonstrate an approach to encapsulate condensed DNA in a PLGA sponge for the purpose of retaining DNA within the matrices and creating efficient gene transfer during tissue engineering. (C) 2003 Wiley Periodicals, Inc. J Biomed Mater Res 67A: 1384-1392, 2003

Key words: controlled release; gene delivery; PEI; plasmid DNA; PLGA; tissue engineering

\section{INTRODUCTION}

Gene delivery has the potential to treat a variety of diseases. Recently, gene therapy found application in tissue engineering by enhancing the rate of cell growth and proliferation ${ }^{1}$ in a polymer scaffold. ${ }^{2}$ To enhance uptake and expression by cells, DNA can be condensed with a polycation to form an electropositive colloidal particle. The DNA condensates resist metabolism by endonucleases and spontaneously transfect cells by binding to their anionic surface. Once internalized, cellular trafficking to the lysosome must be circumvented to efficiently deliver DNA to the nucleus. ${ }^{3}$ Polyethylenimine (PEI) has been identified as a polycation for DNA condensation that mediates efficient gene transfer. ${ }^{4-12}$ The proposed mechanism by which PEI functions is related to its ability to buffer endosomes, which results in osmotic swelling and disrup-

\footnotetext{
Correspondence to: K. G. Rice; e-mail: kevin-rice@ uiowa.edu

Contract grant sponsor: National Institutes of Health; contract grant number: DE13004
}

(C) 2003 Wiley Periodicals, Inc. tion of the endosomes, permitting DNA to escape into the cytosol. ${ }^{4,13,14}$

Our goal is to design and fabricate a biocompatible three-dimensional scaffold to replace the structural and functional characteristics of damaged tissues. The scaffold should display adequate tensile and mechanical strength and be porous, to allow cells to infiltrate and provide for the diffusion of nutrients, metabolites, and growth factors. ${ }^{15}$ Polylactideglycolic acid (PLGA) scaffolds hold promise as tissue engineering matrices because of their ability to be engineered to meet particular requirements for mechanical properties and degradation times. The degradation of PLGA in vivo proceeds by simple hydrolysis, and neither PLGA nor its degradation products are typically associated with significant inflammation, local tissue damage, and local or systemic toxicity in vivo. ${ }^{16}$

Several earlier investigations demonstrated the utility of PLGA for polymer gene delivery in tissue engineering. ${ }^{2}$ Polylactideglycolic acid sponges incorporating plasmid DNA encoding platelet-derived growth factor (PDGF) mediated an increased vascularization near the implant site. ${ }^{2}$ In another example, plasmid DNA encoding pituitary thyroid hormone (PTH) was delivered from a collagen matrix implant and shown 
to accelerate bone growth. ${ }^{19}$ Although the studies provide proof-of-principle, to apply the strategy to bone repair requires increasing the efficiency of gene transfer and retention of DNA in the matrix to allow infiltrating fibroblasts to be transformed.

The current study attempts to advance the concept of PLGA sponges for local gene therapy by combining the transfection efficiency afforded by PEI with the cell migration and ingrowth mediated by porous scaffolds of PLGA. The combined system may result in a sustained and controlled transfection of cells that migrate into the PLGA matrix. Here we report a method to combine PEI DNA condensates with PLGA sponges and evaluate parameters that lead to optimal in vitro gene transfer.

\section{MATERIALS AND METHODS}

\section{Chemicals}

Branched PEI (MW $25 \mathrm{kDa}$ ) was purchased from Sigma/ Aldrich (St. Louis, MO). Sodium chloride and sucrose were purchased from Sigma (St. Louis, MO). Poly (D,L-lactic-coglycolic acid) (PLGA) 85:15 was purchased from Alkermes, Inc. (Cincinnati, OH). Sodium ${ }^{125}$ iodide was purchased from Dupont NEN (Boston, MA). Plasmid DNA (pCMVL) encoding the Photinus pyralis luciferase was purified from Escherichia coli using a Qiagen column (Qiagen, Santa Clarita, CA).

\section{Preparation of PEI DNA condensates}

The PEI DNA condensates were prepared by combining pCMVL in Hepes buffer ( $5 \mathrm{mM}$, pH 7.4) with PEI (10 mM stock) in an equal volume of Hepes buffer. The DNA $(10 \mu \mathrm{g})$ was added dropwise to PEI $(9 \mu \mathrm{g})$ while vortexing. The mixture was then incubated at room temperature (RT) for 30 $\mathrm{min}$. Condensates were prepared at $50 \mu \mathrm{g} / \mathrm{mL}$ and a charge ratio of $0.5-13\left(\mathrm{NH}_{3}^{+}: \mathrm{PO}_{4}^{-}\right)$, corresponding to $1.5-39 \mathrm{nmol}$ of PEI per $\mu \mathrm{g}$ of DNA, respectively.

\section{Particle size analysis of PEI DNA condensates}

The mean particle size of PEI DNA condensates was determined by quasielastic light scattering (QELS) on a Brookhaven ZetaPlus particle sizer. The DNA condensates $(50 \mu \mathrm{g} / \mathrm{mL})$ were prepared as described above followed by the addition of sucrose ( $160 \mu \mathrm{L}$ of $50 \mathrm{w} / \mathrm{v} \%)$ prior to QELS analysis. Condensates were rapidly frozen in dry ice/ethanol with in $2 \mathrm{~min}$, lyophilized overnight, rehydrated with 1 $\mathrm{mL}$ of deionized water, and then reanalyzed by QELS.

\section{Preparation of PLGA sponges}

The PEI DNA condensates were prepared by combining $400 \mu \mathrm{g}$ of plasmid in $4 \mathrm{~mL}$ of Hepes buffer ( $5 \mathrm{mM}$, pH 7.4) with $4 \mathrm{~mL}$ of PEI $(360 \mu \mathrm{g})$. Sucrose $(1 \mathrm{w} / \mathrm{v} \%)$ was added and condensates were rapidly frozen in dry ice and ethanol in 5 min and then lyophilized for $72 \mathrm{~h}$. Freeze-dried PEI DNA condensates were combined with either milled sucrose or sodium chloride (250 to $425 \mu \mathrm{m}$ ) and 85:15 polylactide: glycolide copolymer (106-250 $\mu \mathrm{m})$. Sponges were prepared at $95 \mathrm{wt} \%$ (Porogen: PLGA) by combining $760 \mathrm{mg}$ of sucrose and PEI DNA condensate with $40 \mathrm{mg}$ of PLGA. Alternatively, sponges were prepared at $93,91,89$ and $85 \mathrm{wt} \%$ by adjusting the amount of sucrose and PLGA added. Sponges were fabricated by compression molding $800 \mathrm{mg}$ of the dry mixture at 1500 psi for $1 \mathrm{~min}$ using a $13-\mathrm{mm}$ die set from Pike Technologies (Madison, WI) and a Carver model " $\mathrm{C}$ " hydraulic press (Pike Technologies). The compressed pellet $(2 \times 13 \mathrm{~mm})$ was then foamed into a scaffold via a gas foaming process ${ }^{16}$ in a custom-designed stainless steel highpressure vessel using dry $\mathrm{CO}_{2}$ gas at 800 psi for $24 \mathrm{~h}$. Sponges containing naked DNA also were prepared in an identical fashion as described above.

\section{Average elastic modulus}

Sponges were leached in $25 \mathrm{~mL}$ phosphate-buffered saline (PBS) $\left(137 \mathrm{mM} \mathrm{NaCl}, 2.7 \mathrm{mM} \mathrm{KCl}, 4.3 \mathrm{mM} \mathrm{Na} 2 \mathrm{HPO}_{4}\right.$, and $\left.1.4 \mathrm{mM} \mathrm{KH} \mathrm{PO}_{4}, \mathrm{pH} 7.3\right)$ for $24 \mathrm{~h}$, blotted dry, and then compressed between two plates at a constant deformation rate of $1 \mathrm{~mm} / \mathrm{min}$. The average elastic modulus of gasfoamed sponges was determined on an MTS Bionix 100 mechanical testing machine from Sintech (Research Triangle Park, NC). The stress and strain versus time was recorded and the average elastic modulus was calculated from the slope of the linear region of stress versus strain plot.

\section{DNA release studies}

The ${ }^{125} \mathrm{I}$-labeled plasmid was prepared as described in Terebesi et al. ${ }^{20}$ at a specific activity of $534 \mathrm{nCi} / \mu \mathrm{g}$ DNA. The ${ }^{125}$ I-labeled PEI DNA PLGA sponges were prepared by adding $5 \mathrm{nCi}$ of ${ }^{125}$ I-DNA as a tracer before the formation of PEI DNA condensates. Sponges were incubated in $5 \mathrm{~mL}$ of PBS, and the release of ${ }^{125}$ I-DNA was monitored versus time by gamma counting the PBS followed by replacement with fresh PBS after each measurement.

\section{Scanning electron microscopy}

Sponges were prepared as described above and leached in $25 \mathrm{~mL}$ of PBS for $24 \mathrm{~h}$. Following leaching, sponges were lyophilized overnight and then bisected via freeze fracture. Bisected sponges were sputter coated with a film of goldpalladium alloy (AuPd) and imaged under high vacuum. 
The images were obtained using a Hitachi S-800 field emission SE microscope operating at $5 \mathrm{kV}$.

\section{Gene transfer studies}

The NIH 3 T3 murine fibroblasts (ATCC, Rockville, MD) were cultured in Dulbecco's modified Eagle medium (DMEM; Gibco BRL, Paris, France) supplemented with 10\% fetal bovine serum (FBS, Gibco BRL), $5000 \mathrm{U} / \mathrm{mL}$ penicillin (Gibco BRL) and $5000 \mu \mathrm{g} / \mathrm{mL}$ streptomycin (Gibco BRL) at $37^{\circ} \mathrm{C}$ in a $5 \% \mathrm{CO}_{2}$ humidified atmosphere. Cells were plated at $2 \times 10^{5}$ cells per $35-\mathrm{mm}$ well and incubated for $24 \mathrm{~h}$ to reach approximately $60 \%$ confluence before transfection. All experiments were performed in triplicate. The PEI condensates were prepared at charge ratios of $0.5,1,2,4,7,9,11$, and 13 at a DNA concentration of $50 \mu \mathrm{g} / \mathrm{mL}$. Before transfection, the medium was replaced with DMEM supplemented with $2 \%$ FBS. The condensates $(10 \mu \mathrm{g}$ in $200 \mu \mathrm{L})$ were added dropwise to the culture and incubated for $5 \mathrm{~h}$, at which time the transfecting medium was removed and replaced with DMEM containing 10\% FBS, and cultured for an additional $19 \mathrm{~h}$ before measuring luciferase expression.

Cells were washed twice with ice-cold PBS (calcium and magnesium free) and then treated with $0.5 \mathrm{~mL}$ of ice-cold lysis buffer [25 mM Tris chloride, $\mathrm{pH}$ 7.8, $1 \mathrm{mM}$ ethylene diamine tetraacetic acid (EDTA), $8 \mathrm{mM}$ magnesium chloride, 1\% Triton X-100, $1 \mathrm{mM}$ dithiothreitol, threo-2,3-dihydroxy1,4-dithiolbutane (DTT)] for $10 \mathrm{~min}$. The cell lysate mixture was scraped, transferred to $1.5-\mathrm{mL}$ microcentrifuge tubes, and centrifuged for $7 \mathrm{~min}$ at $13000 \mathrm{~g}$ at $4^{\circ} \mathrm{C}$ to pellet debris. Lysis buffer $(300 \mu \mathrm{L})$, sodium ATP $(4 \mu \mathrm{L}$ of $180 \mathrm{mM}, \mathrm{pH}$ 7, $\left.4^{\circ} \mathrm{C}\right)$, and cell lysate $\left(100 \mu \mathrm{L}, 4^{\circ} \mathrm{C}\right)$ were combined in a test tube, briefly mixed, and immediately placed in the luminometer. Luciferase relative light units (RLU) were recorded on a Lumat LB 9501 (Berthold Systems, Germany) with 10-s integration after automatic injection of $100 \mu \mathrm{L}$ of $0.5 \mathrm{mM}$ D-luciferin (prepared fresh in lysis buffer without DTT). The RLU were converted into picomoles using a standard curve generated by adding a known amount of the enzyme (0.01$100)$ to 6 -well plates containing approximately $60 \%$ confluent 3T3 cells. The cells were processed as described above.

Protein concentrations were measured using the bicinchoninic acid (BCA) assay (Pierce, Paris, France) with bovine serum albumin as a standard. The amount of luciferase recovered in each sample was normalized to milligrams of protein, and the mean and standard deviation obtained from each triplicate were reported. Dose-response curves were generated by varying the dose of DNA while keeping the PEI DNA charge ratio fixed at 7.

The PEI DNA PLGA sponges were sterilized with 95 $\mathrm{v} / \mathrm{v} \%$ ethanol for $30 \mathrm{~min}$, followed by rinsing with PBS for $20 \mathrm{~min}$, and two rinses with DMEM medium for $30 \mathrm{~min}$. The $\mathrm{NIH} 3 \mathrm{~T} 3$ cells (70\% confluent) were trypsinized, suspended in $9 \mathrm{~mL}$ of DMEM medium, and counted in a hemocytometer. A cell suspension of $10^{4}$ cells in $325 \mu \mathrm{L}$ was seeded onto the top of each prewetted sponge and then placed in 24-well plates. The sponges were incubated at $37^{\circ} \mathrm{C}$ in $5 \% \mathrm{CO}_{2}$ for $4 \mathrm{~h}$, followed by the addition of $1 \mathrm{~mL}$ of DMEM. The medium was replaced every 2 days. At the end of the incubation, the medium was removed and the sponges were washed with cold PBS three times, then incubated in $500 \mu \mathrm{L}$ of lysis buffer for $1 \mathrm{~h}$ at $4^{\circ} \mathrm{C}$ while shaking. The sponge was homogenized for $2 \mathrm{~min}$ at $4^{\circ} \mathrm{C}$ in a Polytron homogenizer. The lysis buffer containing the homogenate was centrifuged for $7 \mathrm{~min}$ at $13000 \mathrm{~g}$ at $4^{\circ} \mathrm{C}$ and $100 \mu \mathrm{L}$ of the supernatant was assayed for luciferase and protein as described above.

\section{RESULTS}

\section{Fabrication of PEI DNA PLGA sponges}

A major difficulty of incorporating PEI-condensed DNA into a PLGA sponge is the incompatibility between condensed DNA and the standard techniques used to form the structures. The solvent evaporation technique is most often used to entrap low-molecularweight drugs into PLGA. However, condensed DNA is insoluble in organic solvents used to dissolve PLGA, resulting in inhomogenous matrices when applying classic formulation protocols. In contrast, the gasfoaming technique involves compression of a dry mixture of PLGA microspheres and a pore-forming agent such as sodium chloride under $\mathrm{CO}_{2}$ pressure. Following compression, the release of $\mathrm{CO}_{2}$ causes the PLGA particles to expand into a porous spongelike structure through the pore-forming agent. The advantage of applying gas foaming to the encapsulation of DNA is that the components are blended to form as a dry mixture, thereby eliminating solvent incompatibilities. ${ }^{21}$ The approach was used successfully to encapsulate naked plasmid DNA for the purpose of tissue engineering. ${ }^{2}$ Following a leaching step to remove sodium chloride, the DNA is released from the PLGA sponge, resulting in gene transfer to cells near the PLGA sponge implant site. ${ }^{2}$

To extend the application of the gas-foam methodology to encapsulate DNA, we attempted to incorporate condensed DNA into PLGA gas-foamed sponges. Using this approach, we hoped to enhance the gene transfer efficiency and slow the release rate of DNA so that cells infiltrating into the PLGA matrix would be transformed. To achieve this goal, experiments were first designed to test the particle size stability of freeze-dried DNA condensates. Previous studies compared mannitol, sucrose, and dextran as exipients able to stabilize the particle size of freeze-dried peptide DNA condensates. ${ }^{22}$ Based on the results, which demonstrated sucrose to be the best lyoprotectant, similar studies were conducted with PEI DNA condensates to determine excipients that would preserve the particle size (Fig. 1). In the presence of Hepes buffer, either with or without $1 \mathrm{w} / \mathrm{v} \%$ sodium chloride, the particle size of PEI DNA condensates were large $(>200 \mathrm{~nm})$ both before and after freeze drying. The addition of sucrose appeared to optimally preserve the particle 


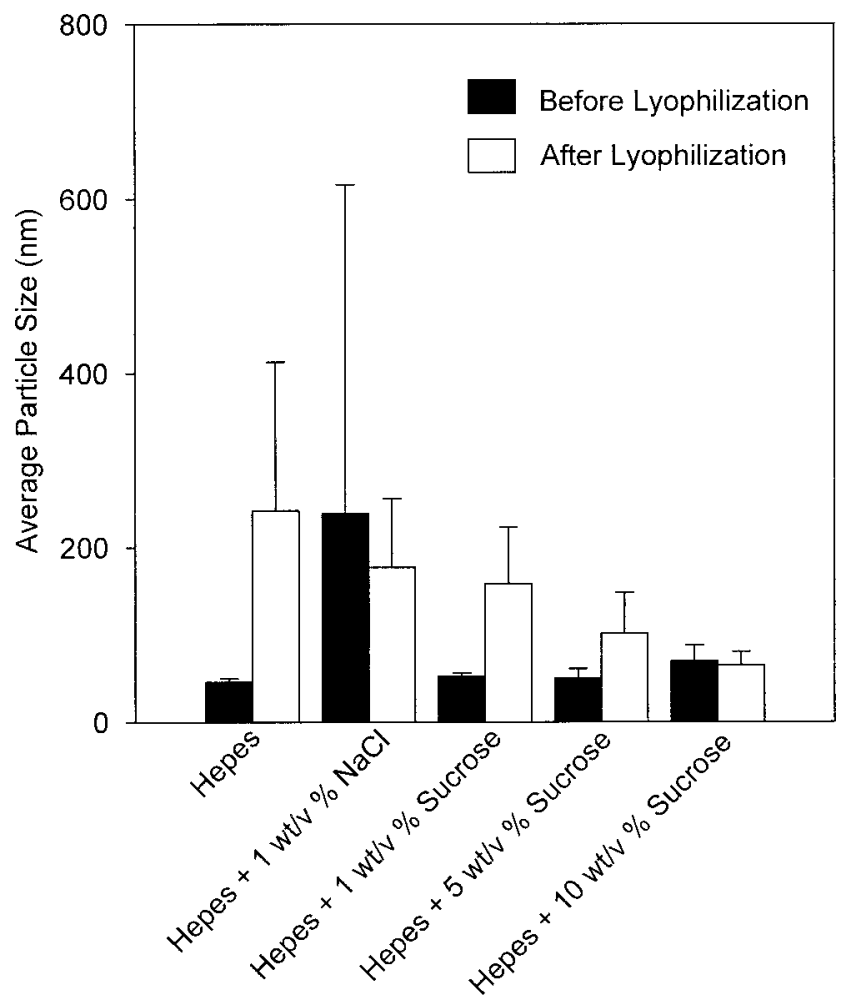

Figure 1. Particle size of PEI DNA condensates. The QELS particle size for PEI DNA condensates before and after freeze drying with different lyoprotectants is illustrated.

size following freeze drying, such that the addition of $10 \mathrm{w} / \mathrm{v} \%$ sucrose maintained a particle size of less than $100 \mathrm{~nm}$ after freeze drying (Fig. 1).

The PLGA sponges were fabricated with varying weight ratios of sucrose in an attempt to match results obtained with sodium chloride. The mechanical strengths of PLGA sponges fabricated with sucrose or sodium chloride as a porogen were compared by measuring their elastic moduli. Although sodium chloride was used in the gas-foaming encapsulation of naked DNA, we hypothesized that sucrose would be a more suitable porogen for PEI DNA sponges. ${ }^{23}$ The ionic interactions that bind PEI to DNA can be disrupted at high sodium chloride concentration, leading to the rapid dissolution of naked DNA from a PEI DNA sponge. The results presented below are in agreement with this proposal.

Alternatively, the results also establish that scaffolds formed using $91 \mathrm{wt} \%$ sucrose have an elastic modulus comparable to (100 $\mathrm{kPa})$ scaffolds prepared using $95 \mathrm{wt} \%$ sodium chloride (Fig. 2). Lowering the wt $\%$ of sucrose to $89 \%$ or $85 \%$ produced a proportional increase in the elastic modulus.

The porosity of each sponge was calculated by the following equation: Porosity $(\%)=\{1-[($ dry wt $/$ vol $) /$ polymer density] $\} \times 100$. The calculated porosities of the sponges containing 85-95 $\mathrm{wt} \%$ sucrose ranged from $94 \%$ to $98 \%$, respectively. All formulations pos- sess a porosity of greater than $90 \%$, which was desired to support minimal cell ingrowth. Scanning electron micrographs confirmed that PLGA sponges fabricated with either sodium chloride or sucrose as the porogen were highly porous (Fig. 3).

The release of radioiodinated DNA from PLGA sponges prepared with sucrose or sodium chloride were compared. The results indicated that PEI DNA sponges prepared with $95 \mathrm{wt} \%$ sodium chloride released $100 \%$ of the entrapped DNA within 2 days (Fig. 4). Similar results were obtained with the release of naked DNA from a PLGA sponge prepared with 91 $w \mathrm{t} \%$ sucrose. In contrast, less than $20 \%$ of PEI DNA condensates were released during 15 days from sponges prepared with $85,89,91$, and $95 \mathrm{wt} \%$ sucrose, respectively (Fig. 4). The rapid release of PEI DNA from sponges prepared with $95 \mathrm{wt} \%$ sodium chloride was presumably the result of dissociation of PEI DNA from the anionic PLGA matrices (Fig. 4).

\section{Gene expression mediated by PEI DNA}

To optimize gene transfer from PLGA sponges, experiments were first designed to measure expression mediated by PEI DNA added directly to adherent cells while varying key parameters. The charge ratio of PEI

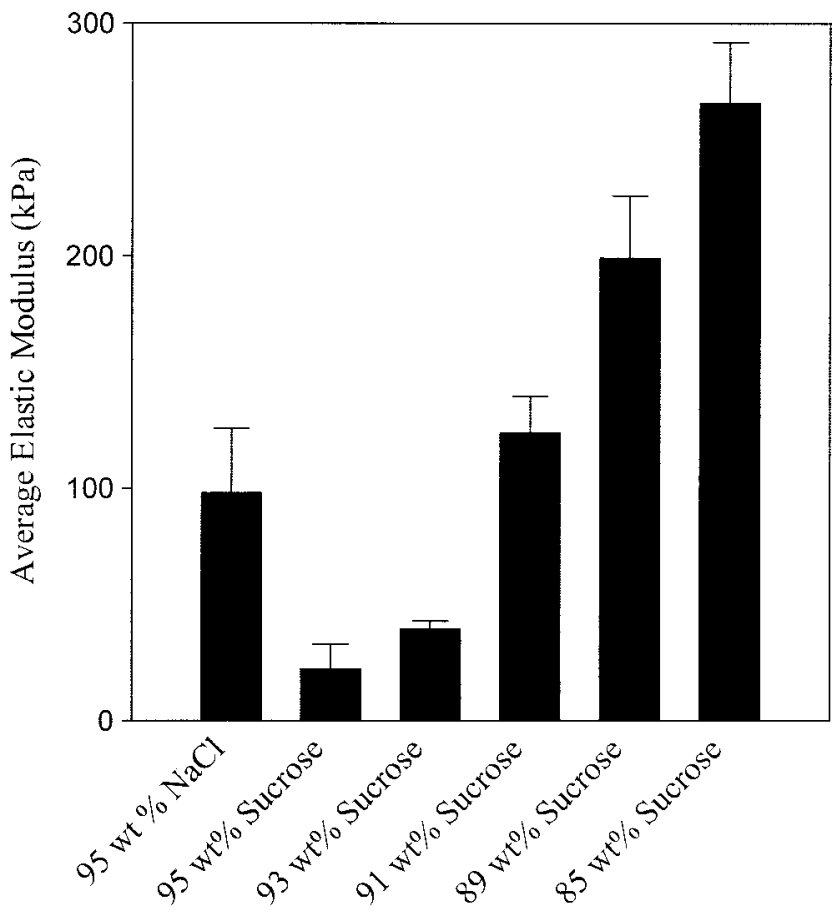

Figure 2. Mechanical integrity of gas-foamed sponges. The mechanical modulus of leached PLGA sponges prepared with different porogens is illustrated. Each bar represents the average elastic modulus of five sponges. 
A

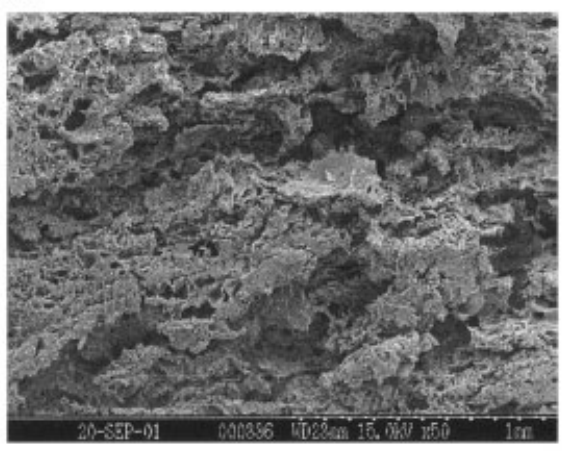

$\mathrm{C}$

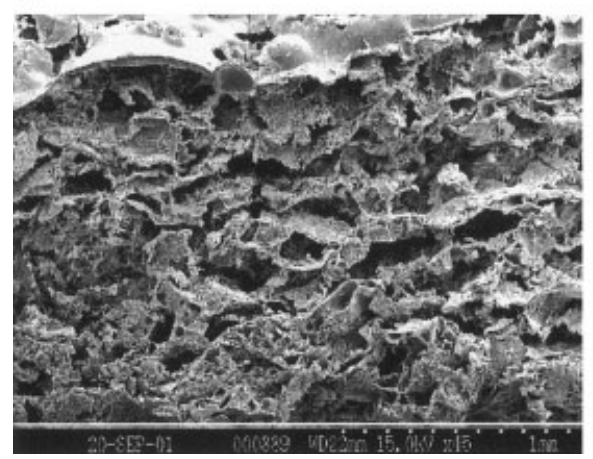

B

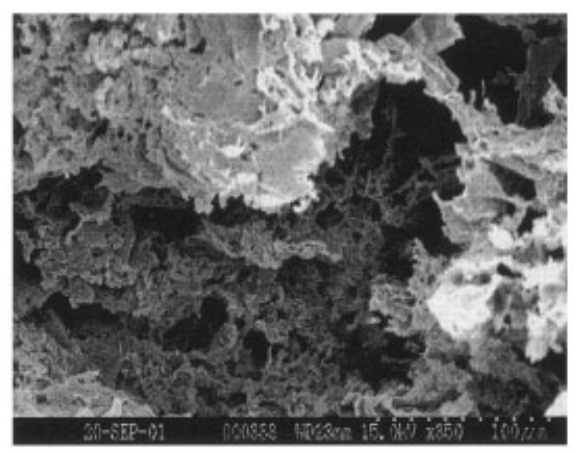

D

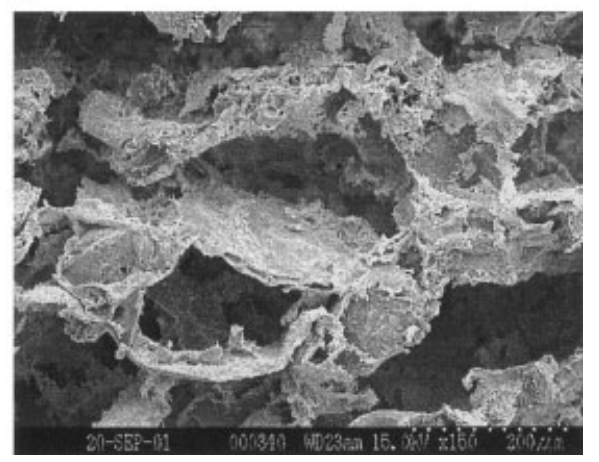

Figure 3. Scanning electron micrographs of gas-foamed sponges. The surface pore structure of sponges prepared with 91 wt $\%$ sucrose at $\times 50$ (original magnification) (A) and $\times 350$ (original magnification) (B) are compared with similar images prepared with $95 \mathrm{wt} \%$ sodium chloride at $\times 45$ (original magnification) (C) and $\times 150$ (original magnification) (D). The scale of each micrograph is shown in the lower right corner of each panel.

to DNA was systematically changed from 0.5 to 13 to establish a charge ratio of 7 , which produced nearly maximal gene expression while minimizing excess PEI that could be harmful to cells [Fig. 5(A)].

Fixing the charge ratio at 7 , the cell seeding number was varied, resulting in an optimal expression when $10^{5}$ cells were added to wells. At a cell seeding number fourfold higher, the gene expression decreased by nearly 10 -fold, likely because of cells reaching confluency, causing cessation of cell division [Fig. 5(B)].

The time course of gene expression was examined at a fixed PEI to DNA charge ratio of 7 and cell seeding number of $10^{5}$ [Fig. 5(C)]. Maximal expression occurred at $24 \mathrm{~h}$, followed by an exponential decline, resulting in nearly 10 -fold less gene expression after $96 \mathrm{~h}$ [Fig. 5(C)]. A dose-response experiment established a nearly linear relationship from 2 to $50 \mu \mathrm{g}$ of DNA, after which increasing DNA further did not increase the level of gene expression [Fig 5(D)].

Analysis of the in vitro gene expression mediated by PEI DNA PLGA required a slightly modified protocol in which cells were introduced onto a sponge placed in the cell culture plate. After an appropriate incubation period, infiltrating and adherent cells were harvested from the sponge and assayed for luciferase. Control experiments established that pipetting cells

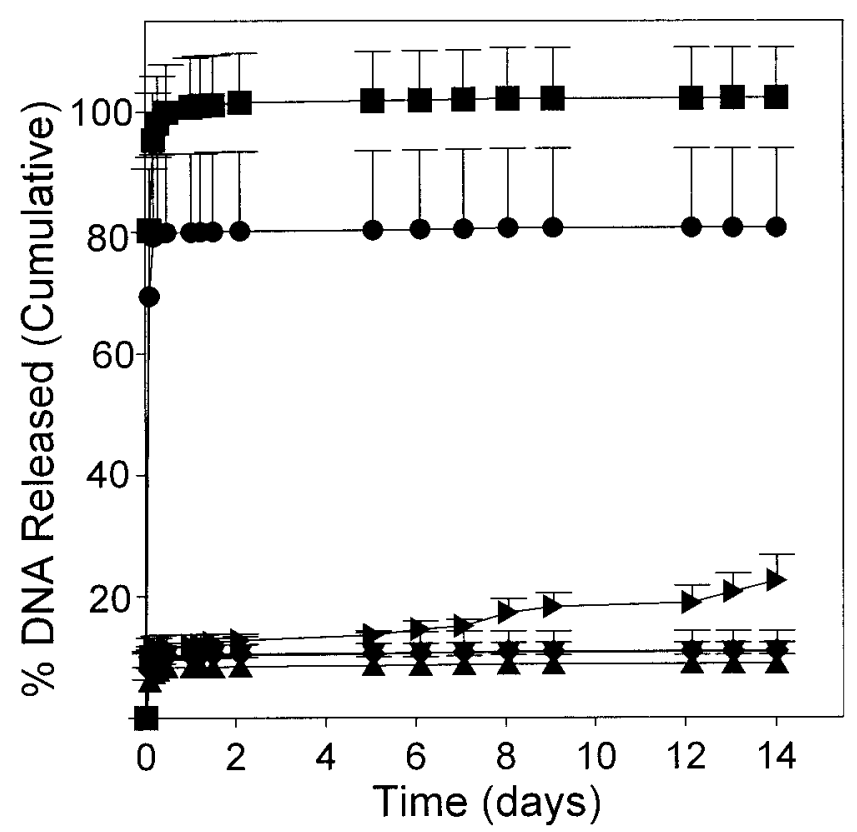

Figure 4. The DNA release from PLGA sponges. The release of PEI ${ }^{125}$ I-DNA condensates from sponges prepared with 85 wt $\%(\Delta), 89 \mathrm{wt} \%(\nabla), 91 \mathrm{wt} \%(\bullet)$, and $95 \mathrm{wt} \%(\boldsymbol{\nabla})$ sucrose are compared with sponges prepared with $95 \mathrm{wt} \%$ sodium chloride $(\boldsymbol{\square})$. In addition, the release of naked ${ }^{125}$ I-DNA from a sponge prepared with $91 \mathrm{wt} \%(\bullet)$ sucrose was tested. 

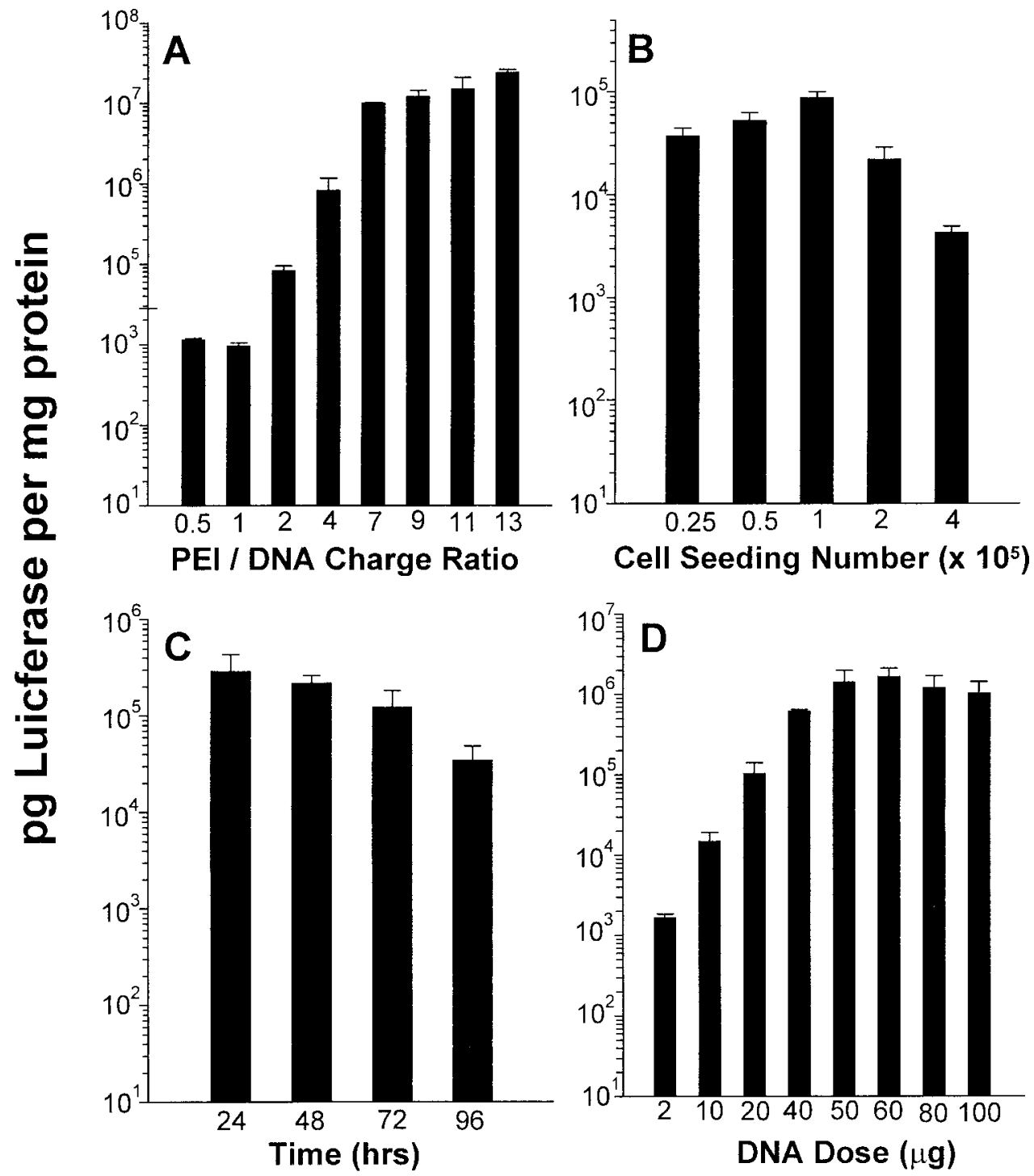

Figure 5. In vitro gene expression of PEI DNA in NIH 3T3 cells. Luciferase reporter gene expression for PEI DNA condensates as a function of PEI DNA charge ratio (A), cell seeding number (B), gene expression time course (C), and DNA dose (D) is illustrated. Each bar represents the mean and standard deviation of the triplicate transfections.

onto the sponge promoted adherence and infiltration compared with overlaying a PLGA sponge onto already adherent cells (data not shown). Further control studies also confirmed that only cells that adhered to or infiltrated into the PLGA sponge expressed reporter gene, whereas cells that were adherent to the culture plate were not transformed (data not shown).

By comparison, the gene transfer efficiency mediated by PEI DNA PLGA sponges containing $50 \mu \mathrm{g}$ of DNA was approximately 100 -fold lower relative to direct gene transfer of $10 \mu \mathrm{g}$ of PEI DNA to adherent cells (Fig. 6). The difference between the two is that in the latter case nearly all of the DNA is immediately available to cells, whereas in the former, the majority of the DNA remains entrapped and inaccessible to cells external to the sponge over this time.

Comparison of the expression mediated by PEI
DNA PLGA sponges prepared with $85-95 \%$ sucrose as a porogen established maximal expression at days 3-6, which declined threefold or fourfold by day 15 (Fig. 6). The gene transfer efficiency was indistinguishable for sponges prepared with $85 \%, 89 \%$, or $91 \%$ sucrose but increased severalfold for sponges prepared with $95 \%$ sucrose. This likely resulted from a decrease in the cell growth and associated protein recovered from the culture, because of the mechanical instability of $95 \mathrm{wt} \%$ PLGA sponges. Interestingly, PEI DNA sponges prepared with sodium chloride as the porogen (85-95 $\mathrm{wt} \%$ ) were completely inactive in gene transfer as were PLGA sponges containing naked DNA (not shown). These data support the hypothesis that sodium chloride caused rapid loss of PEI DNA during the leaching step. The results also established that the gene transfer was much more sustained when 


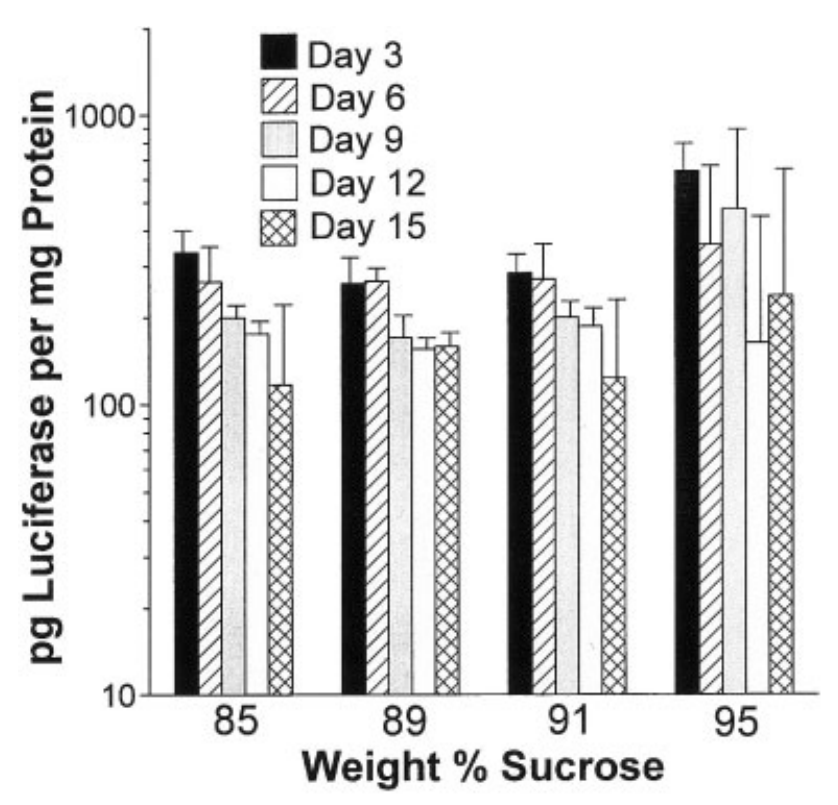

Figure 6. Time course of gene expression from PEI DNA PLGA sponge. The luciferase gene expression during days 3-15 for PLGA sponges prepared using 85, 89, 91, and 95 $\mathrm{wt} \%$ sucrose are illustrated relative to a control sponges prepared with $91 \%$ sucrose and naked DNA. Each sponge contained $50 \mu \mathrm{g}$ of DNA seeded with $10^{4}$ cells.

transforming cells in PLGA sponges compared with direct gene transformation of adherent cells.

The level of gene expression was influenced by the number of cells seeded onto PLGA sponges but was not significantly different between the optimal range of $10^{5}-10^{6}$ cells (Fig. 7). As observed when transform-

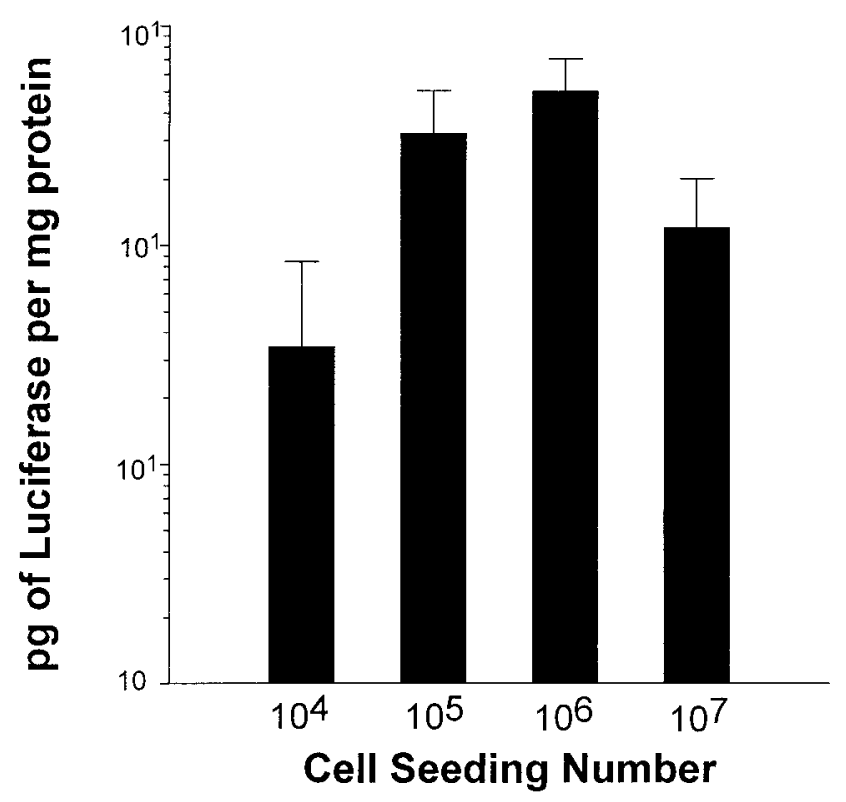

Figure 7. Influence of cell seeding number on PEI DNA gene transfer from PLGA sponges. The cell seeding number was varied from $10^{4}$ to $10^{7}$ for gene transfer from PLGA sponges prepared with $91 \mathrm{wt} \%$ sucrose and $50 \mu \mathrm{g}$ of PEI DNA while measuring luciferase expression at day 3.

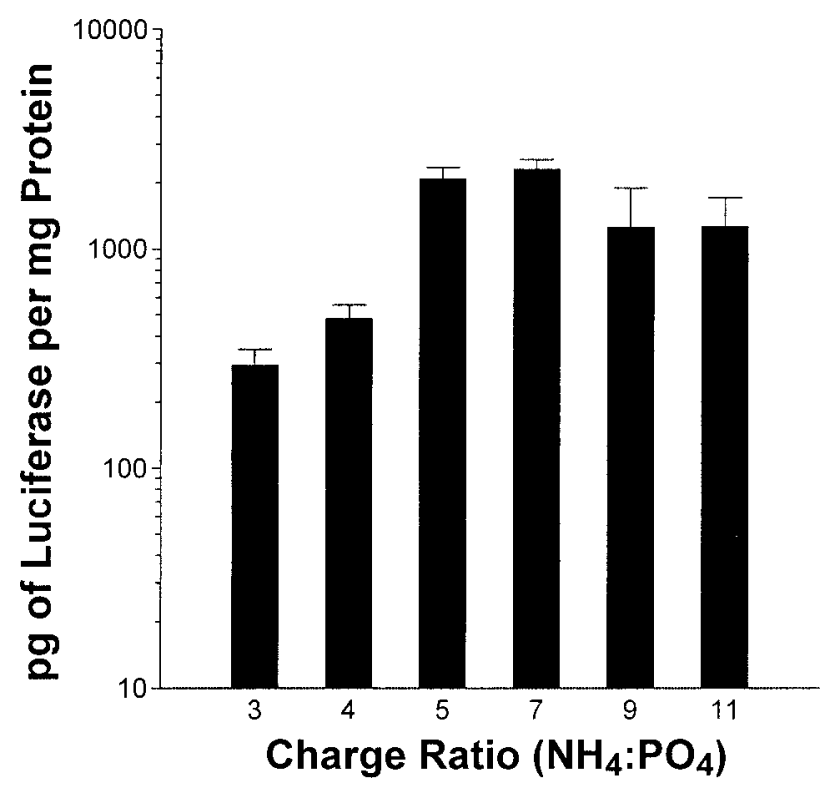

Figure 8. Influence of PEI DNA charge ratio on gene transfer from PLGA sponges. The PEI DNA charge ratios were varied from 0.5 to 11 in PLGA sponges prepared with 91 $\mathrm{wt} \%$ sucrose and $50 \mu \mathrm{g}$ of DNA.

ing adherent cells, the charge ratio strongly influenced the expression mediated by PEI DNA entrapped in PLGA sponges, with a maximal gene expression at a charge ratio of 5 or higher (Fig. 8).

The dosing range was varied from 2 to $1000 \mu \mathrm{g}$ in PEI DNA sponges prepared with $91 \mathrm{wt} \%$ sucrose. The results indicated a flat dose response between 2 and 20 $\mu \mathrm{g}$, followed by a proportional dose response up to $250 \mu \mathrm{g}$, with no additional increase up to $1000 \mu \mathrm{g}$ of DNA (Fig. 9).

\section{DISCUSSION}

In a previous study, naked plasmid DNA was incorporated into a PLGA sponge and used to demonstrate its utility in tissue engineering in vivo. ${ }^{2}$ The DNA encoding either $\beta$-galactosidase or PDGF was combined with sodium chloride, freeze dried, and then used to make PLGA sponges in a procedure analogous to that presented here. The DNA-loaded PLGA sponges were leached to remove sodium chloride, then implanted in a subcutaneous pouch in rats. Two notable consequences of this experiment were that a large percentage of the DNA was released from the sponge prematurely during the leaching step, and cells external to the sponge implant were transformed. ${ }^{2}$

In the current study, we attempted to improve on the previous design by entrapping PEI DNA in the PLGA sponge, allowing transfection of infiltrating cells, with higher gene transfer efficiency relative to 


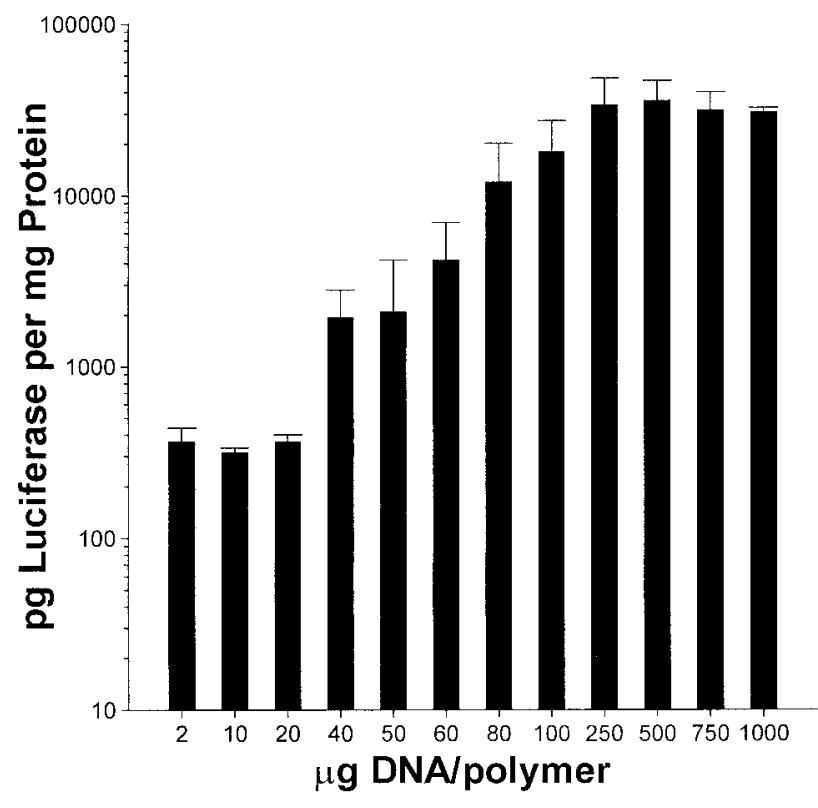

Figure 9. Dose response for PEI DNA PLGA sponges. Luciferase expression levels were compared for PEI DNA PLGA sponges prepared with $91 \mathrm{wt} \%$ sucrose while varying the dose of DNA from 2 to $1000 \mu \mathrm{g}$.

that achievable with naked DNA. To accomplish these goals, we attempted to incorporate PEI DNA condensates, which are known to be efficient mediators of gene transfer in vitro and in vivo. To formulate dry PEI DNA condensates with an appropriate porogen and granular PLGA, we first established that sucrose was compatible with the gas-foaming process and simultaneously would preserve the particle size of DNA condensates. Using the elastic modulus as a measure of sponge stability, $91 \mathrm{wt} \%$ sucrose was found to substitute for $95 \mathrm{wt} \%$ sodium chloride, whereas lower sucrose concentrations were able to produce sponges that were significantly more stable.

In addition to being compatible with the gas-foaming technique, sucrose facilitated the retention of PEI DNA within the sponge during the leaching step. As demonstrated in Figure 4, very little of the DNA is released over time, suggesting it is bound through electrostatic interactions with PLGA. Sucrose was thus found to be a substitute porogen that resulted in retention of condensed DNA in the sponge while maintaining the porocity and mechanical stability of the sponge.

Although the gene transfer properties of PEI DNA condensates were studied previously, ${ }^{24,25}$ we sought to compare the efficiency of gene transfer using optimal conditions of charge ratio, dose, cell seeding number, and time of expression with and without a PLGA sponge in a fibroblast cell line. The results indicate that although direct gene transfer of PEI DNA condensate onto adherent cells produces a higher level of gene expression, the duration is much shorter compared with gene transfer from a PLGA sponge. Likewise, only cells that bind to and infiltrate into the pores of the PLGA sponge are transformed. This is consistent with the location of the PEI DNA, which remains inaccessible to cells outside the matrices.

It is interesting to speculate on the mechanism of gene transfer within the PLGA matrices. Presumably, infiltrating cells encounter immobilized PEI DNA and capture it from the surface of the PLGA sponge. Consequently, at low PEI DNA loading levels, the gene transfer is relatively inefficient because of the infrequent encounters of PEI DNA and infiltrating cells, whereas at optimal loading, PEI DNA is more densely dispersed throughout the matrices, resulting in either the transformation of more cells or multiple transfection events for cells penetrating further into the matrices. At very high loading levels, PEI DNA may form aggregates within the matrices that sequester the DNA, making it less accessible for gene transfer.

It is also clear that the PEI DNA charge ratio strongly influences the gene transfer efficiency. At a charge ratio of 2:1 or higher, DNA is fully condensed and can no longer bind additional PEI. However, excess PEI is likely retained in the PLGA sponge through electrostatic interaction and can participate in gene transfer via a mechanism that is proposed to involve the disruption of endosomes, allowing the escape of DNA.

Although PEI DNA is known to exert toxicity to cells when delivered in high concentrations, ${ }^{23,26}$ we found no evidence of cellular toxicity from PEI DNA PLGA sponges when conducting dose-response experiments. Likewise, based on the measurement of total cellular protein, PEI was not found to be toxic to cells at charge ratios $(\mathrm{N}: \mathrm{P})$ as high as 11:1. This may be a result of sequestration of the excess PEI on the surface of PLGA surface until the time of cellular encounter. The PEI would be expected to ionically bind to PLGA, making it less able to crosslink proteins on the cell surface, leading to membrane disruption.

Future studies will examine the ability of PEI DNA PLGA sponges to mediate gene expression in vivo, with the aim of using the scaffold to direct cellular infiltration and formation of tissue.

\section{References}

1. Cohen H, Levy RJ, Gao J, Fishbein I, Kousaev V, Sosnowski S, et al. Sustained delivery and expression of DNA encapsulated in polymeric nanoparticles. Gene Ther 2000;7:1896-1905.

2. Shea LD, Smiley E, Bonadio J, Mooney DJ. DNA delivery from polymer matrices for tissue engineering. Nat Biotechnol 1999; 17:551-554.

3. Fradkin LG, Ropp JD, Warner JF. Gene-based therapeutics. In: Lanza RP, Langer R, Vacanti J, editors. Principles of tissue engineering. San Diego, CA: Academic Press; 2000. p 385-406.

4. Boussif O, Lezoualc'h F, Zanta MA, Mergny MD, Scherman D, Demeneix B, et al. A versatile vector for gene and oligonucle- 
otide transfer into cells in culture and in vivo: polyethylenimine. Proc Natl Acad Sci USA 1995;92:7297-7301.

5. Boletta A, Benigni A, Lutz J, Remuzzi G, Soria MR, Monaco L. Nonviral gene delivery to the rat kidney with polyethylenimine. Hum Gene Ther 1997;8:1243-1251.

6. Gautam A, Densmore CL, Golunski E, Xu B, Waldrep JC. Transgene expression in mouse airway epithelium by aerosol gene therapy with PEI-DNA complexes. Mol Ther J Am Soc Gene Ther 2001;3:551-556.

7. Lemkine GF, Demeneiz BA. Polyethylenimines for in vivo gene delivery. Curr Opin Mol Ther 2001;3:178-182.

8. Boussif O, Zanta MA, Behr JP. Optimized galenics improve in vitro gene transfer with cationic molecules up to 1000-fold. Gene Ther 1996;3:1074-1080.

9. Kircheis R, Kichler A, Wallner G, Kursa M, Ogris M, Felzmann $\mathrm{T}$, et al. Coupling of cell-binding ligands to polyethylenimine for targeted gene delivery. Gene Ther 1997;4:409-418.

10. O'Neill MM, Kennedy CA, Barton RW, Tatake RJ. Receptormediated gene delivery to human peripheral blood mononuclear cells using anti-CD3 antibody coupled to polyethylenimine. Gene Ther 2001;8:362-368.

11. Blessing T, Kursa M, Holzhauser R, Kircheis R, Wagner E. Different strategies for formation of PEGylated EGF-conjugated PEI/DNA complexes for targeted gene delivery. Bioconj Chem 2001;12:529-537.

12. Lee H, Jeong JH, Park TG. A new gene delivery formulation of polyethylenimine/DNA complexes coated with PEG conjugated fusogenic peptide. J Cont Rel 2001;76:183-192.

13. Godbey WT, Wu KK, Mikos AG. Tracking the intracellular path of poly(ethylenimine)/DNA complexes for gene delivery. Proc Natl Acad Sci USA 1999;96:5177-5181.

14. Godbey WT, Barry MA, Saggau P, Wu KK, Mikos AG. Poly(ethylenimine)-mediated transfection: A new paradigm for gene delivery. J Biomed Mater Res 2000;51:321-328.

15. Kim BS, Mooney DJ. Development of biocompatible synthetic extracellular matrices for tissue engineering. Trends Biotechnol $1998 ; 16: 224-230$
16. Wong WH, Mooney DJ. Synthesis and properties of biodegradable polymers used as synthetic matrices for tissue engineering. In: Atata A, Mooney D, Editors. Synthetic biodegradable polymer scaffolds. Boston, MA: Birkhauser; 1997. p 51-82.

17. Harris LD, Kim BS, Mooney DJ. Open pore biodegradable matrices formed with gas foaming. J Biomed Mater Res 1998; 42:396-402.

18. Thomsen RC, Mikos AG, Beahm E, Lemon JC, Satterfield WC, Aufdemorte TB, et al. Guided tissue fabrication from periosteum using preformed biodegradable polymer scaffolds. Biomaterials 1999;20:2007-2018.

19. Bonadio J, Goldstein SA, Levy RJ. Gene therapy for tissue repair and regeneration. Adv Drug Deliv Rev 1998;33:53-69.

20. Terebesi J, Kwok KY, Rice KG. Iodinated plasmid DNA as a tool for studying gene delivery. Anal Biochem 1998;263:120123.

21. Mooney DJ, Baldwin DF, Suh NP, Vacanti JP, Langer R. Novel approach to fabricate porous sponges of poly(D,L-lactic-coglycolic acid) without the use of organic solvents. Biomaterials 1996;17:1417-1422.

22. Kwok KY, Adami RC, Hester KC, Park Y, Thomas S, Rice KG. Strategies for maintaining the particle size of peptide DNA condensates following freeze-drying. Int J Pharm 2000;203:8188 .

23. Adami RC, Collard WT, Gupta SA, Kwok KY, Bonadio J, Rice KG. Stability of peptide-condensed plasmid DNA formulations. J Pharm Sci 1998;87:678-683.

24. Tang MX, Szoka FC. The influence of polymer structure on the interactions of cationic polymers with DNA and morphology of the resulting complexes. Gene Ther 1997;4:823-832.

25. Abdallah B, Hassan A, Benoist C, Goula D, Behr JP, Demeneix BA. A powerful nonviral vector for in vivo gene transfer into the adult mammalian brain: polyethylenimine. Hum Gene Ther 1996;7:1947-1954.

26. Goula D, Benoist C, Mantero S, Merlo G, Levi G, Demeneix BA. Polyethylenimine-based intravenous delivery of transgenes to mouse lung. Gene Ther 1998;5:1291-1295. 